Aliran Eksistensialisme dalam Pandangan Filsafat Pendidikan Islam

Rabiatul Adawiah

Madrasah dan Transformasi Intelektual Muhdi

Kisah Keluarga Teladan dalam Al-Qur'an (Inspirasi Membangun Negara yang Thayyibah) Rahmat Sholihin

Tasawuf dalam Pandangan Nurcholish Madjid Ilham Masykuri Hamdie dalam Buku The Tao of Islam) Erni Susilawati

Islam, Keindonesiaan, dan Kemanusiaan

(Telaah Pemikiran Ahmad Syafii Maarif) Damanhuri

Pandangan Kritis Islam Liberal atas Isu-Isu Kontemporer Muhammad Taufik 


\section{AL - BANJARI \\ Jurnal Ilmiah Ilmu-Ilmu Keislaman}

Vol. 14, No. 1, Januari-Juni 2015

\section{DAFTAR ISI}

Aliran Eksistensialisme dalam Pandangan Filsafat Pendidikan Islam

Rabiatul Adawiah

Madrasah dan Transformasi Intelektual

Muhdi

Kisah Keluarga Teladan dalam Al-Qur'an (Inspirasi Membangun

Negara yang Thoyyibah)

Rahmat Sholihin

Tasawuf dalam Pandangan Nurcholish Madjid

Ilham Masykuri Hamdie

Psikologi Sufistik (Studi atas Pemikiran Sachiko Murata dalam Buku

The Tao of Islam)

60-75

Erni Susilawati

Islam, Keindonesiaan, dan Kemanusiaan (Telaah Pemikiran

Ahmad Syafii Maarif)

$76-84$

Damanhuri

Pandangan Kritis Islam Liberal atas Isu-Isu Kontemporer

85-105

Muhammad Taufik 


\title{
ALIRAN EKSISTENSIALISME DALAM PANDANGAN FILSAFAT PENDIDIKAN ISLAM
}

\author{
Rabiatul Adawiah \\ Fakultas Dakwah dan Komunikasi Islam \\ IAIN Antasari Banjarmasin.
}

\begin{abstract}
Existentialism is a philosophy that emphasizes on individual existence and self-fulfillment. Each individual is seen as being unique, and must take personal responsible for his fate. Existentialism is closely related to education because they both talk about the same issues, such as human life, human relations, the nature of personality, and freedom. Islam views that humans have potentials to be developed since the day they were born. Islam gives a very noble position to humans. The ultimate goal of Islamic education is striving to realize a perfect individual muslim who can carry out its function as an 'abid and caliph on the earth.
\end{abstract}

Keywords: Existentialism, Existence, Education and Islam.

\section{Pendahuluan}

Masalah pendidikan merupakan masalah yangberhubungan langsung dengan hidup dan kehidupan manusia. Pendidikan adalah usaha sadar dari manusia dewasa yang telah sadar akan kemanusiaannya, dalam membimbing, melatih, mengajar dan menanamkan nilai-nilai serta dasar-dasar pandangan hidup kepada generasi selanjutnya, agar menjadi manusa yang sadar dan bertanggung jawab akan tugasnya sebagai manusia, sesuai dengan sifat dan hakikat kemanusiaannya.

Lebih luas masalah pendidikan adalah masalah yang menyangkut seluruh aspek hidup dan kehidupan manusia. Bahkan pendidikan juga menghadapi persoalanpersoalan yang tidak mungkin dijawab dengan mengguakan analisa ilmiah sematamata, tetapi memerlukan analisa dan pemikiran yang mendalam, yaitu analisa filsafat.

Hubungan fungsional antara filsafat dan teori pendidikan tersebut, secara lebih rinci dapat diuraikan:Pertama, Filsafat, dalam arti analisa filsafat adalah merupakan salah satu cara pendekatan yang digunakan oleh para ahli pendidikan dalam memecahkan problematika pendidikan dan menyusun teori-teori pendidikannya, disamping menggunakan metode ilmiah lainnya; Kedua, Filsafat, juga berfungsi memberikan arah agar teori pendidikan yang telah dikembangkan oleh para ahlinya, yang berdasarkan dan menurut pandangan dan aliran filsafat tertentu memiliki relevansi dengan kehidupan nyata; Ketiga, Filsafat, termasuk juga filsafat pendidikan, 
juga mempunyai fungsi untuk memberikan petunjuk dan arah dalam pengembangan teori-teori pendidikan menjadi ilmu pendidikan atau paedagogik. ${ }^{1}$

Imam Barnadib seperti yang dikutip oleh Jalaluddin dan Usman Said mengatakan, bahwa filsafat pendidikan adalah ilmu yang pada hakikatnya merupakan jawaban dari persoalan-persoalan dalam lapangan pendidikan dan merupakan penerapan suatu analisa filosofis terhadap lapangan pendidikan. ${ }^{2}$

Hubungan antara pendidikan dan filsafat pendidikan akan semakin penting, karena filsafat pendidikan menjadi dasar yang menjadi tumpuan suatu sistem pendidikan. Filsafat pendidikan menjadi pedoman bagi usaha-usaha perbaikan, meningkatkan kemajuan dan sebagai dasar yang kokoh bagi tegaknya sistem pendidikan. Selama masih ada pertanyaan; "Mengapa kita mengajar? Bagaimana kita mengajar? Untuk apa kita mengajar?", maka selama itu pula pendidikan akan selalu memerlukan filsafat khususnya filsafat pendidikan.

Esensialisme, perenialisme, progresivisme, rekonstruksionisme dan eksistensialisme merupakan refleksi dari pemikiran pendidikan (teori pendidikan) yang masing-masing mendasarkan pada pemikiran filosofis, idealisme, realisme, pragmatisme, eksistensialisme. Artinya teori-teori pendidikan terbentuk bersumber dari aliran-aliran filsafat.

Kajian ini, mencoba membatasi diri dengan menguraikan salah satu dari aliran filsafat sekaligus teori pendidikan, yakni eksistensialisme yang tentunya mempunyai relevansi dengan pengembangan pendidikan barat dan Islam. Untuk itu akan kita telaah eksistensialisme ini dengan mengungkapkan beberapa persoalan sebagai berikut:

1. Bagaimana latar belakang munculnya eksistensialisme?

2. Bagaimana eksistensialisme dan tokoh-tokohnya?

3. Bagaimana aspek ontologi, epistemologi, dan aksiologi dalam eksistensialisme?

4. Bagaimana eksistensialismedalam pendidikan?

5. Bagaimana eksistensialisme dan Islam?

Mudahan-mudahan telaahan ini mampu menjawab kelima persoalan di atas dan memberikan wawasan pengetahuan khususnya filsafat pendidikan Islam kepada kita semua, Amin.

\section{Sekilas Latar Belakang Munculnya Eksistensialisme}

Filsafat selalu lahir dari suatu krisis. Dalam filsafat eksistensi, manusia dijadikan tema sentral, hal ini menunjukkah bahwa di Barat sedang berjangkit suatu krisis yang luar biasa hebatnya. Bagaimana keadaan krisis itu?

1. Materialisme

Sifat materialisme ternyata merupakan pendorong lahirnya eksistensialisme. Yang dimaksud dengan eksistensi ialah cara orang berada di dunia. Kata berada pada manusia tidak sama dengan beradanya pohon atau batu. Untuk menjelaskan arti kata

1 Zuhairini, Filsafat Pendidikan Islam (Jakarta : Bumi Aksara, 1992), hlm. 16-17.

2 Jalaluddin dan Usman Said, Filsafat Pendidikan Islam (Jakarta: PT RajaGrafindo Persada, 1994), hlm. 11. 
berada bagi manusia, aliran eksistensialisme mula-mula menghantam materialisme. ${ }^{3}$

Dalam pandangan materialisme, baik yang kolot maupun yang modern, manusia pada akhirnya adalah benda seperti halnya kayu dan batu. Orang materialis memang tidak mengatakan bahwa manusia sama dengan benda seperti kayu dan batu. Namun, materialisme mengatakan bahwa pada akhirnya, pada prinsipnya, pada dasarnya, pada instansi yang terakhir, manusia hanyalah sesuatu yang material; dengan kata lain betul-betul materi. Berdasarkan bentuknya, manusia lebih unggul dari batu, kayu dan sebagainya, tetapi pada eksistensinya manusia sama saja dengan kayu dan batu. Dilihat dari keberadaannya juga sama. Inilah ajaran materialisme yang menjadi yang ditolak sekaligus menjadi penyebab munculnya eksistensialisme. ${ }^{4}$

2. Idealisme

Idealisme juga menjadi penyebab munculnya eksistensialisme. Kalau materialisme memandang jasmani manusia sebagai keseluruhan manusia, sebagai sesuatu yang ada, padahal ia hanyalah aspek manusia dan menjadi subjek. Manusia berpikir, berkesadaran dan ini yang tidak disadari oleh materialisme. Maka idealisme sebaliknya, manusia berpikir dan berkesadaran sangat dilebih-lebihkan sehingga menjadi seluruh manusia, bahkan sampai tidak ada barang lain selain pikiran.

Ahmad Tafsir mengatakan letak kesalahan idealisme adalah karena memandang manusia hanya sebagai subjek, hanya sebagai kesadaran. Sebaliknya materialisme melihat manusia hanya sebagai objek. Materialisme dan idealisme sama-sama salah, tetapi dapat tersebar luas, memperoleh banyak penganut, memikat hati banyak orang. Ini memperlihatkan bahwa sulit bagi manusia untuk mengerti dirinya sendiri. Rupanya manusia iu semacam rahasia bagi dirinya. ${ }^{5}$ Eksistesialisme lahir atas reaksi terhadap idealisme.

\section{Situasi dunia}

Eksistensialisme muncul didorong oleh situasi dunia saat itu. Keadaan dunia khususnya Eropa Barat tidak menentu. Rasa takut berkecamuk, terutama terhadap ancaman perang. Tingkah laku manusia telah menimbulkan krisis. Kebencian merajalela. Agama di Eropa dianggap tidak mampu memberikan makna dalam kehidupan. Manusia menjadi orang yang gelisah, mereka eksistensinya terancam oleh ulahnya sendiri. Pokoknya, manusia benar-benar mengalami krisis. Dalam keadaan seperti itu, filosof melihat pada dirinya sendiri. Ia mengharap pegangan yang dapat menyelamatkan, keluar dari krisis itu. Maka dari itu tampillah eksistensialisme yang menjadikan manusia sebagai subjek dan sekaligus objek. ${ }^{6}$

Jadi eksistensialisme lahir, karena ingin menempatkan kembali diri manusia pada tempat yang sebenarnya. Manusia sebagai subjek sekaligus sebagai objek. Manusia tidak sama dengan materi, manusia tidak hanya akal dan manusia memerlukan kebahagiaan, ketenangan dan kedamaian.

\footnotetext{
${ }^{3}$ Ahmad Tafsir, Filsafat Umum, Akal dan Hati Sejak. Thales Sampai Capra. (Bandung: PT Remaja Rosdakarya, 2003), hlm. 219.

${ }^{4}$ Ibid., hlm., 219.

5 Ibid., hlm., 221.

${ }^{6}$ Ibid., hlm., 222.
} 


\section{Eksistensialisme dan Tokoh-Tokohnya \\ Pengertian Eksistensialisme}

Eksistensialisme yaitu suatu usaha untuk menjadikan masalah menjadi konkret karena adanya manusia dan dunia. Menurut Sartre eksistensialisme yaitu filsafat yang memberi penekanan eksistensi yang mendahului esensi. Memandang segala gejala yang ada berpangkal kepada eksistensi. Dengan adanya eksistensi akan penuh dengan lukisan-lukisan yang konkret dengan metode fenomenologi (cara keberadaan manusia).

Eksistensialisme, berakal dari kata "eksistensi", dalam bahasa Inggris "existence" adalah bentuk kata benda, dengan kata kerja "to exist" yang berarti "the state of being..." Ia berasal dari bahasa latin "existo" dan exister". Dalam bahasa Prancis: "existo", yakni terdiri dari "ex" dan "sisto", yang berarti to stand. Semuanya itu dalam bahasa Indonesia berarti secara harfiah, "berdiri' atau 'menempatkan diri'. Kata "ex" berarti keluar. "To exist" di samping pengertian seperti di atas juga secara harfiah berarti: keluar, ada, hidup, atau mengada. Akan tetapi dalam eksistensialisme, artinya lebih kompleks, tidak cukup "ada", "mengada" atau "berada".

Eksistensialisme adalah filsafat yang memandang segala gejala dengan berpangkal kepada eksistensi. Secara umum eksistensi berarti keberadaan. Secara khusus eksistensi adalah cara manusia berada di dalam di dunia. Cara manusia berada di dalam dunia berbeda dengan cara berada benda-benda. Benda-benda tidak sadar akan keberadaannya. Berbeda dengan manusia. Benda-benda menjadi lebih berarti karena manusia. Untuk membedakan dua cara berada ini di dalam filsafat eksistensialisme dikatakan, bahwa benda-benda "berada", sedangkan manusia "bereksistensi". Jadi hanya manusia yang bereksistensi. ${ }^{8}$

Eksistensi diartikan manusia berdiri sebagai diri sendiri dengan keluar dari dirinya. Manusia sadar bahwa dirinya ada. Ia dapat meragukan segala sesuatu, tapi satu hal yang pasti, yaitu bahwa dirinya ada. Dirinya itu disebut "aku". Segala sesuatu di sekitarnya dihubungkan dengan dirinya contoh mejaku, kursiku, temanku,dan sebagainya. Di dalam dunia manusia menentukan keadaanya dengan perbuatan-perbuatannya. Ia mengalami dirinya sebagai pribadi. Ia menemukan pribadinya dengan seolah-olah keluar dari diriya sendiri dan menyibukkan diri dengan apa yang di luar dirinya. Ia menggunakan benda-benda disekitarnya. Dengan kesibukannya itulah ia menemukan dirinya sendiri. Ia berdiri sebagai diri sendiri dengan keluar dari dirinya dan sibuk dengan dunia luarnya. Demikianlah manusia bereksistensi.

Sedangkan filsafat eksistensialisme adalah aliran filsafat yang menyatakan bahwa cara berada manusia dan benda lain tidaklah sama. Manusia berada di dalam dunia; ia menyadari dirinya berada di dunia. Manusia menghadapi dunia, menghadapi dengan mengerti yang dihadapinya itu. Manusia mengerti guna pohon, batu dan salah satu di antaranya ialah ia mengerti bahwa hidupnya mempunyai arti. Artinya bahwa manusia sebagai subjek. Subjek artinya yang menyadari, yang sadar. Barang-barang yang disadarinya disebut objek. ${ }^{9}$

\footnotetext{
${ }^{7}$ Muzairi. Eksistensialisme Jean Paul Sartre, (Yogyakarta: Pustaka Pelajar, 2002), h. 28.

${ }^{8}$ Harun Hadiwijono, Sari Sejarah Filsafat Barat 2 (Yogyakarta: Kanisius, 1980), hlm. 149.

${ }^{9}$ Ahmad Tafsir, op.cit., hlm. 220.
} 
Ajaran eksistensialisme tidak hanya satu. Sebenarnya eksistensialisme adalah aliran filsafat yang bersifat tehnis, yang menjelma dalam bermacam-macam sistem, yang satu berbeda dengan yang lain. Sekalipun demikian ada juga ciri-ciri yang sama, yang menjadikan sistem-sistem itu dapat dicap sebagai filsafat eksistensialisme. Paling sedikit ada empat pemikiran yang jelas dapat disebut filsafat eksistensialisme, yaitu pemikiran Martin Heidegger, Jean Paul Sartre, Karl Jaspers dan Gabriel Marcel. Beberapa ciri-ciri yang sama yang dimiliki di antaranya:

1. Motif pokok adalah apa yang disebut eksistensi, yaitu cara manusia berada. Hanya manusia yang bereksistensi. Eksistensi adalah khas manusia berada. Pusat perhatian ini ada pada manusia. Oleh karena itu bersifat humanitis.

2. Bereksistensi harus diartikan secara dinamis. Bereksistensi berarti menciptakan dirinya secara aktif, bereksistensi berarti berbuat, menjadi, merencenakan. Setiap saat manusia menjadi lebih atau kurang dari keadaanya.

3. Di dalam filsafat eksistesialisme manusia dipandang sebagai terbuka. Manusia adalah realitas yang belum selesai, yanng masih harus dibentuk. Pada hakikatnya manusia terikat kepada dunia sekitarnya, terutama kepada sesama manusia.

4. Filsafat eksistensialisme memberi tekanan kepada pengalaman yang konkret, pengalaman eksistensial. Hanya arti pengalaman ini berbeda-beda. Heidegger memberi tekanan kepada kematian, yang menyuramkan segala sesuatu, Marcel kepada pengalaman keagamaan dan Jaspers kepada pengalaman hidup yang bermacam-macam seperti kematian, penderitaan, perjuangan dan kesalahan. ${ }^{10}$

Eksistensi merupakan keadaan tertentu yang lebih khusus dari sesuatu. Apapun yang bereksistesi tentu nyata ada. Sesuatu dikatakan bereksistensi jika sesuatu itu bersifat publik yang artinya objek itu sendiri harus dialami oleh banyak orang yang melakukan pengamatan.

Jadi eksistensialisme betul-betul berusaha mengungkap manusia yang utuh sebagai eksistensi yang mendahului essensinya, sebab eksistensi manusia itu bukanlah selesaimantap, akan tetapi sebaliknya, terus mengada. Manusia menyadari keterbatasannya serta temporalitsnya. Lewat itulah dia membuka kemungkinan-kemungkinan sambil memproyeksikan dirinya ke depan, karena ia adalah makhluk temporal. Eksistensi memandang makhluk manusia adalah yang paling sadar waktu. Masa lalu, masa depan dan masa kini adalah tunggal dalam penghayatannya. Bahkan yang lebih khas masa kini dengan segala kondisi perangkatnya dikonstitusikan sebagai potensi bagi masa depannya yang diselipi dengan kekuatiran dan kecemasan.

Maka eksistensialisme pada umumnya menyadari betul posisi manusia dalam kesejarahannya, yang melibatkan rentangan eksistensi antara kekuatan konservatif yang berasal dari masa lalunya, serta kekuatan-kekuatan progresif yang berasal dari proyeksi masa depan. Pada rentang kekuatan itu manusia tidak mungkin menghindarkan diri dari ketegangan, kecemasan, kejenuhan hidup serta kekuatirannya. Masa lalu tidak

\footnotetext{
${ }^{10}$ Harun Hadiwijono, loc. cit.
} 
kenal pengulangan, masa depan baru dirancang, hanya masa kini yang pasti, dan itulah eksistensi. ${ }^{11}$

Keunikan filsafat eksistensialisme yaitu memfokuskan pembahasan pada masalah-masalah individu. Dimana, eksistensialisme memberi individu suatu jalan berpikir mengenai kehidupan, apa maknanya bagi saya, apa yang benar untuk saya. Secara umum, eksistensialisme menekankan pilihan kreatif, subjektifitas pengalaman manusiadan tindakan konkret dari keberadaan manusia atas setiap skema rasional untuk hakikat manusia atau realitas. Dari perspektif eksistensialisme, pendidikan sejatinya adalah upaya pembebasan manusia dari belenggu-belenggu yang mengungkungnya sehingga terwujudlah eksistensi manusia ke arah yang lebih humanis dan beradab.

\section{Tokoh-Tokoh Eksistensialisme dan Pemikirannya}

Beberapa pemikiran eksistensialisme dapat menjadi landasan atau semacam bahan renungan bagi para pendidik agar proses pendidikan yang dilakukan semakin mengarah pada keotentikan dan pembebasan manusia yang sesungguhnya. Untuk itu, marilah kita pelajari bagaimana pendapat para tokoh filsafat eksistensialisme:

\section{a. Soren Aabye Kierkegaard}

Kierkegaard lahir di Kopenhagen, Denmark pada 5 Mei 1813, sebagai anak bungsu dari tujuh bersaudara. Ayahnya, Michael Pedersen Kierkegaard, merupakan pedagang grosir yang menjual kain, pakaian, dan makanan. Setelah mengenyam pendidikan di sekolah putra yang prestisius di Borgerdydskolen, ia melanjutkan pendidikan tingginya di Universitas Kopenhagen. Di sini pria yang bernama lengkap Soren Aabye Kierkegaard ini mempelajari filsafat dan teologi. Sejumlah tokoh seperti F.C. Sibbern, Poul Martin Moller, dan H.L. Martensen menjadi gurunya di sana.

Ia dianggap sebagai bapak eksistensialisme. Bagi Kierkegaard eksistensi berarti: kepenuhan ada, dalam mana individu karena persetujuannya dan kemauannya yang merdeka, yaitu karena sikapnya terhadap manusia dan barang lain, menjadikan dirinya subjek yang konkrit yang ada pada tiap-tiap saat. Ia berpendapat demikian, karena menurut dia kebenaran itu tidaklah terdapat pada suatu system yang umum melainkan ada yang konkrit, dalam eksistensi yang individual. Maka menurut Kierkegaard dalam eksistensi kita (manusia) itu ternyatalah, bahwa kita itu merasa bersalah (berdosa) terhadap Tuhan. Eksistensi manusia ialah berdosa (ada yang mempunyai dosa). ${ }^{12}$

Menurut Kierkegaard, kepercayaan terhadap Tuhan adalah suatu tindakan transendental yang dimungkinkan karena Tuhan memberikan kesempatan kepada manusia untuk mengatasi dirinya dan menghadap kepada-Nya; menghadap dengan kesejatiannya, ... sebab: "God is the one who does not grow tired of listening to men." (Tuhan adalah satu-satunya yang tidak pernah lelah mendengarkan manusia).

Ia mengkritik orang yang hanya secara sepintas tahu tentang agama, berpikir tentang agama dan berbicara tentang agama. Agama harus dihayati sebagai pengalaman subjektif. Kierkegaard menekankan bahwa yang yang menjadi soal bukanlah agama itu sendiri, melainkan bagaimana menjalani suatu eksistensi beragama. ${ }^{13}$

\footnotetext{
${ }^{11}$ Muzairi. op.cit., hlm. 44.

${ }^{12}$ I.R. Poedjawijatna, Pembimbing ke Arah Alam Filsafat (Jakarta: Rineka Cipta, 1994), hlm. 143.

${ }^{13}$ M. Solihin. Perkembangan Pemikiran Filsafat dari Klasik. Hingga Modern.( Bandung: Pustaka Setia,
} 
Eksistensi individu sendirilah yang merupakan satu-satunya realitas yang secara actual bisa dipahami, dan eksitensialisme individunya sendiri yang merupakan subjek atau pelaku pemahaman ini. Eksistensinya adalah eksistensi yang berpikir, tetapi pemikirannya ditentukan kehidupan individualnya, sehingga semua problemnya timbul dan dipecahkan dalam aktivitas individualnya. ${ }^{14}$

Inti pemikirannya adalah eksistensi manusia bukanlah sesuatu yang statis tetapi senantiasa menjadi, manusia selalu bergerak dari kemungkinan menuju suatu kenyataan, dari cita-cita menuju kenyataan hidup saat ini. Jadi ditekankan harus ada keberanian dari manusia untuk mewujudkan apa yang ia cita-citakan atau apa yang ia anggap kemungkinan.

\section{b. Karl Jaspers,}

Karl Jaspers lahir di kota Oldenburg, Jerman Utara, pada tahun 1883. Ayahnya seorang ahli hukum dan direktur bank. Sejak sekolah menengah, ia sudah tertarik pada filsafat, tetapi baru pada usia 38 tahun ia dapat sepenuhnya memenuhi panggilan filosofisnya. ${ }^{15}$

Karl Jaspers mencurahkan seluruh perhatiannya pada filsafat mulai tahun 1921, setelah ia menerima gelar profesor filsafat di Heidelberg. Ada yang tak setuju dengan pemberian gelar ini, sebab ia dianggap bukan filosof profesional. Namun, setelah menerima gelar penghargaan itu, ia menulis banyak sekali karya, antara lain karya besar yang terdiri dari tiga jilid,Philosophie (1932). ${ }^{16}$

Pokok persoalan filsafat yang paling peting baginya adalah bagaimana dapat menangkap "ada" atau "berada" (das Sein) dalam eksistensi sendiri. Menurut Jasper "ada" bukanlah hal yang objektif, yang dapat diketahui semua orang. Orang harus mencarinya dengan susah payah dengan melalui beberapa tahap. Sebuah benda yang konkrit bukanlah "ada" dalam arti umum. Benda tertentu yang konkrit itu (meja, kursi, dan sebagainya) adalah suatu "ada" tertentu, yang terbatas. Maka benda bukanlah seluruh "ada". "Ada" dalam arti yang sebenarnya, "ada" yang umum, meliputi, merangkumkan segala yang berada secara terbatas dan tertentu. "Ada" ini dapat diraih, tidak dapat dimasukkan ke dalam kategori. "Ada" yang demikian ini disebut das Ungreifende (yang merangkumi). ${ }^{17}$

2007), hlm. 256-259.

${ }^{14}$ Herbert Marcuse, Rasio dan Revolusi, Terjemahan(Yogyakarta: Pustaka Pelajar, 2004), hlm. 221.

${ }^{15}$ Selama tiga semester ia belajar hukum di Universitas Heidelberg dan Munchen, tetapi ia mengubah haluan dengan memilih studi kedokteran yang dijalankan di Berlin, Gottingen dan Heidelberg. Di Universitas Heidelberg ia mengambil spesialiasi psikiatri. Tetapi ia tetap tertarik dengan filsafat, antara lain melalui Max Weber, ahli ekonomi, sejarawan dan sosiolog terkenal yang dikaguminya.Jaspers menulis buku Allgemeine Psychopathologie (Psikologi umum) pada tahun 1910. Di buku ini, ia tidak melukiskan penyakit-penyakit, tetapi menyoroti manusia yang sakit. Ia menggunakan metode deskripsi fenomenologis Husserl. Pada 1916 ia menjadi profesor psikologi di Heidelberg. Lalu pada 1919 ia menulis buku Psychologie der Weltanschanungen (Psikologi Tentang Pandangan-Pandangan Dunia). Di buku ini, ia melukiskan berbagai sikap yang diambil manusia terhadap kehidupan. Dua buku ini ditulis berdasarkan pengalamannya sebagai psikiater dan menunjukkan betapa kentalnya ketertarikan Karl Jaspers pada filsafat.

${ }^{16}$ Harun Hadiwijono, op. cit., hlm. 165

${ }^{17}$ Ibid., hlm. 165. 
Agar kita mengerti apa yang disebut eksistensi oleh Jaspers, kita harus mulai dengan menganalisa situasi dengan menganalisa apa yang olehnya disebut situasi. Di dalam situasi ini secara eksistensial kita menemukan diri kita sendiri. Situasi ini satu dari diri kita, yang sebagai oknum hidup di dalamnya. Eksistensi diungkapkan sebagai perbuatan, sebagai pemilihan, sebagai kebebasan. Bagaimana kita dapat tahu akan eksistensi kita dalam mengalami secara khusus kebebasan sebagai kekbebasan dan pemilihan? Hanya jikalau kita sadar, bahwa perbuatan yang kita lakukan itu kita lakukan sendiri, keluar dari kekuatan dan kehendak kita, serta dari putusan kita sendiri. ${ }^{18}$

\section{c. Martin Heidegger}

Martin Hiedegger ${ }^{19}$ (lahir di Messkirch, Jerman, 26 September $1889 \pm$ meninggal 26 Mei 1976 pada umur 86 tahun) merupakan pemikir yang ekstrim, hanya beberapa filosof saja yang mengerti pemikiran Heidegger. Pemikiran Heidegger ${ }^{20}$ selalu tersusun secara sistematis. Tujuan dari pemikiran Heidegger pada dasarnya berusaha untuk menjawab pengertian dari 'being'. Heidegger berpendapat bahwa 'Das Wesen des Daseins liegtinseiner Existenz', adanya keberadaan itu terletak pada eksistensinya. Di dalam realitasnya being (sein) tidak sama sebagai 'being' ada pada umumnya, sesuatu yang mempunyai ada dan di dalam ada, dan hal tersebut sangat bertolak belakang dengan ada sebagai pengada. Heidegger menyebut being sebagai eksistensi manusia, dan sejauh ini analisis tentang 'being' biasa disebut sebagai eksistensi manusia (Dasein). Dasein adalah tersusun dari da dan sein. 'Da' disana (there), 'sein' berarti berada (to be/ being). Artinya manusia sadar dengan tempatnya.

Bagi Heidegger, pemaknaan terhadap manusia harus dilihat secara ontologisme, yakni kehadiran manusia dalam pentas kehidupan sudah menjadikan dirinya sebagai care ata concern, keprihatinan atau keterlibatan dengan segala yang berada di sekelilingnya. ${ }^{21}$

Dasein, baginya sebagai being ini the world. Sebagai ada dalam dunia sudah melibatkan dirinya terhadap sesuatu, menggunakan sesuatu, memproduksi, menelitit, mempertanyakan, mengerjakan, memanipulasi, memakai, menyelesaikan, mempertimbangkan, menentukan, mendiskusikan, dan lain sebagianya. Keberadaan ${ }^{18}$ Ibid., hlm. 170.

${ }^{19}$ Martin Heidegger lahir pada tanggal 26 September 1889 di kota kecil Messkirch Baden, Jerman. Ia adalah anak seorang pastor pada gereja katolik Santo Mortus. Martin Heidegger mempunyai pengaruh besar terhadap beberapa filosof di Eropa dan Amerika Selatan. Ia menerima gelar Doktor dalam bidang filsafat dari Universitas Freiburg dimana ia belajar dan menjadi asisten Edmund Husserl (penggagas fenomelogi). Sebelumnya ia kuliah di fakultas Teologi sampai empat semester, lau pindah filsafat di bawah bimbingan Heinrich Rickert, penganut filsafat Neo-Kantianisme yang juga banyak memberi pengaruh padanya.Ia pernah menjabat sebagai guru besar filsafat di Universitas Masburg dan berkenalan dengan teolog protestan kenamaan Rodolf Bultmann, kemudian kembali ke Freiburg untukk menggantikan Huserl. Di Marburg ia sempat menyelesaikan karya monumental Sein und Zeit (Being and Time). Pada 1993, ia di angkat oleh gerakan Nazi menjadi rektor pertama di Universitas Freiburg. Sadar kalau dirinya dieksploitasi, setahun kemudian ia meletakkan jabatan rektornya, tapi tetap mengajar sampai pensiun 1957.

${ }^{20}$ Atang Abdul Hakim dan Beni Ahmad Saebeni, Filsafat Umum : Dari Mitologi Sampai Teofilosofi, (Bandung: Pustaka Setia, 2008), hlm. 334.

${ }^{21}$ Zaprulkhan, Filsafat Umum: Sebuah Pendekatan Tematik (Jakarta: PT. RajaGrafindo Persada, 2012), hlm. 142 
manusia adalah berhubungan dengan manifestasi potensi mereka sebagai kemungkinan-kemungkinan eksistensi yang tidak pernah selesai potensi mereka sebagai kemungkinan-kemungkinan eksistensi yang tidak pernah selesai, sekaligus menyatu atau terikat dengan keberadaan benda-benda lain yang mengitarinya. Namun, fakta yang menggelisahkan adalah mayoritas manusia era abad ke-21 terkerangkeng dalam siklus kecepatan, konsumeristik, dan kedangkakalan hidup yang hanya berpijak pada hasrat semata, sehingga banyak yang merasa hampa dan kehilangan makna.

Atas dasar kenyataan itulah, Heidegger ingin menyibak makna "ada" melalui ontologi fundamental. Ia berusaha menyelidiki makna "ada" yang mengada di situ (dasein), yang tidak lain adalah eksistensi manusia sendiri. Persoalan eksistensi manusialah yang kemudian menjadi perhatian dan unit analisis filsafat Heidegger, sehingga filsafatnya sering disebut juga "Analisis Eksistensial". 22

\section{d. Jean Paul Sartre}

Jean Paul Sartre ${ }^{23}$ ialah yang dianggap mengembangkan aliran eksistensialisme. ${ }^{24}$ Sartre adalah seorang sastrawan dan filosof Perancis terkenal yang memperkenalkan eksistensialisme dari sudut pandang atau perspektif estetika. Sartre sangat terkesan dengan nasib manusia, termasuk nasib dirinya, khususnya terkesan dengan pengalaman buruknya ketika perang dunia II di Eropa. Setelah kejatuhan Prancis oleh Nazi Jerman tahun 1940, ia bergabung dengan tentara Prancis untuk mempertahankan negaranya. Pengalamannya selama perang dunia II ini mengilhami pandangan-pandangannya tentang manusia dan kebebasan.

Menurut Sartre titik tolak filsafat adalah kesadaran (cogito), yaitu kesadaran yang saya miliki tentang diri saya sendiri. Dalam hal ini Sartre mengikuti jalan pikiran Descartes. Tetapi kesadaran diri itu tidaklah tertutup, melainkan terarah pada dunia sebagaimana dikatakan Husserl. Selanjutnya, jalan pikiran Sartre adalah sebagai berikut: Kesadaran akan diri berbeda dengan kesadaran akan sesuatu. Suatu kesadaran yang tidak sadar atau suatu aktivitas psikis yang tidak sadar sama sekali mustahil menurut Sartre. Kalau saya sadar sesuatu berarti saya bukan sesuatu itu.Saya melihat lukisan di dinding sana atau gelas the di meja sini, itu berarti saya sadar bahwa saya bukanlah lukisan atau gelas.

Untuk melihat sesuatu diperlukan adanya jarak. Bila sesuatu itu dekat sekali dengan mata apalagi sesuatu identik dengan mata (misalnya retina atau selaput jala), saya tidak akan melihat apa-apa. Di sini disimpulkan bahwa manusia sanggup mengakan relasi dengan yang tidak ada. Kesadaran berarti distansi, jarak, nonidentitas. Maka, kesadaran berarti sama dengan kebebasan. ${ }^{25}$

${ }^{22}$ Ibid., hlm. 143. Lihat Juga Zainal Abidin, Filsafat Manusia (Bandung: Rosdakarya, 2003), hlm. 155.

${ }^{23}$ Ia lahir di Paris, Perancis, 21 Juni 1905 M. dan meninggal di Paris, 15 April 1980 pada umur 74 tahun. Ia adalah seorang filosof dan penulis Perancis. Ia adalah filosof atheis. Itu dinyatakannya terang-terangan. Konsekuensi pandangan atheis itu ialah tuhan tidk ada, atau sekurang-kurangnya manusia bukan ciptaan Tuhan. Oleh karena itu, konsepnya tentang manusia ialah manusia bukan ciptaaan Tuhan. Dari pemikirannya itu ia menemukan bahwa eksistensi manusia mendahului esensinya.

${ }^{24}$ Lebih lengkap lihat Muzairi, Eksistensialisme jean Paul Sartre. Op. Cit. h. 71.

${ }^{25}$ Arif Rohman, Rukiyati, L. Andriani. Epistemologi dan Logika: Filsafat untuk Pengembangan Pendidikan. (Yogyakarta: Aswaja Pressindo, 2014), hlm. 115. 
Sartre menyatakan, eksistensi lebih dulu ada dibanding esensi. Manusia tidak memiliki apa-apa saat dilahirkan dan selama hidupnya ia tidak lebih hasil kalkulasi dari komitmen-komitmennya di masa lalu. Karena itu, menurut Sartre selanjutnya, satu-satunya landasan nilai adalah kebebasan manusia.

\section{e. Friedrich Nietzshe}

Friedrich Nietzshe lahir di Rohen Jerman pada tanggal 15 Oktober tahun 1844, lahir di Rocken, Prusia, Jerman Timur, di lingkungan keluarga Kristen yang taat. Ayahnya seorang pendeta Lutheran terkemuka dengan garis kependetaan yang terwaris dari turun temurun dari keluarga ayahnya. Kakeknya adalah pedeta Gereja Lutheran yang menduduki jabatan cukup tinggi, sementara ibunya juga seorang penganut Kristen yang taat.

Nietzcshe berpendapat bahwa kebenaran adalah hasil konstruksi atau ciptaan manusia sendiri, yang berjiwa bagi mereka untuk melestarikan diri sebagai spesis. Pengetahuan dan kebenaran sebagai perangkat yang efektif untuk mencapai tujuan bukan entitas yang trasenden dari manusia. Kebenaran ilmiah tidak mungkin efektif karena hasil konstruksi manusia dan selalau upaya melayani kepentingan dan tujuan tertentu manusia. ${ }^{26}$

Menurutnya, manusia yang bereksistensi adalah manusia yang mempunyai keinginan untuk berkuasa (will to power), dan untuk berkuasa manusia harus menjadi manusia super yang mempunyai mental majikan bukan mental budak. Dan kemampuan ini hanya dapat dicapai dengan penderitaan karena dengan menderita orang akan berfikir lebih aktif dan akan menemukan dirinya sendiri. Pemikiran filsafat Nietzsche terarah pada upaya melahirkan ide yang bisa menjadi jalan keluar untuk menjawab pertanyaan filosofisnya, yaitu "bagaimana cara menjadi manusia unggul". Jawabannya adalah manusia bisa menjadi unggul jika mempunyai keberanian untuk merealisasikan diri secara jujur dan berani.

\section{Aspek Ontologi, Epistemologi, dan Aksiologi dalam Eksistensialisme}

1. Ontologis (Realitas)

Manusia secara individual adalah unik. Karena ia unik, ia adalah "yang berada secara sadar dalam dunia". Maka manusia pun sadar akan diri dalam dunianya. Manusia adalah personal yang rasional sekaligus irrasional, personal yang berpikir juga merasakan, personal yang kognitif juga afektif. ${ }^{27}$ Realitas adalah kenyataan hidup itu sendiri. Untuk menggambarkan realitas, kita harus menggambarkan apa yang ada dalam diri kita, bukan yang ada diluar kondisi manusia. Bagi eksistensialisme, bendabenda materi, alam fisik, dunia yang berada diluar manusia tidak akan bermakna atau tidak memiliki tujuan apa-apa kalau terpisah dari manusia. Jadi, dunia ini bermakna karena manusia. ${ }^{28}$

2. Epistemologis (Pengetahuan)

Epistemologi eksistensialisme beranggapan bahwa individu itu bertanggung

\footnotetext{
${ }^{26}$ M. Solihin. op.cit. h. 259.

${ }^{27}$ Arif Rohman, Rukiyati, L. Andriani.Arif Rohman, Rukiyati, L. Andriani, op.cit., hlm.114.

${ }^{28}$ Harun Hadiwijono, op cit., hlm. 148 dan Ahmad Tafsir, op. cit., hlm. 218.
} 
jawab terhadap pengetahuannya sendiri. Pengetahuan itu berasal dari dalam diri, yaitu kesadaran individu dan perasaan-perasaannya sebagai hasil pengalaman masingmasing individu. Manusia menghadapi situasi yang dibangun dari komponen yang rasional maupun yang irrasional. Keabsahan suatu pengetahuan ditentukan oleh nilai dan maknanya bagi individu secara khusus. ${ }^{29}$ Pengetahuan manusia tergantung pada pemahamannya tentang realitas dan tergantung pada interpretasi manusia terhadap realitas.

\section{Aksiologi (Nilai)}

Pemahaman eksistensialisme pada nilai, menekankan kebebasan dalam tindakan. Manusia memiliki kebebasan untuk memilih, namun menentukan pilihanpilihan diantara pilihan-pilihan yang terbaik adalah yang paling sukar. Berbuat akan menghasilkan akibat, dimana seseorang harus menerima akibat-akibat tersebut sebagai pilihannya. Kebebasan tidak pernah selesai, karena setiap akibat akan menghasilkan kebutuhan untuk pilihan berikutnya.Pendidikan sejatinya adalah upaya pembebasan manusia dari belenggu-belenggu yang mengurungnya. Sehingga terwujudlah eksistensi manusia ke arah yang lebih humanis dan beradab. Beberapa pemikiran eksistensialisme dapat menjadi landasan atau semacam bahan renungan bagi para pendidik agar proses pendidikan yang dilakukan semakin mengarah pada pembebasan manusia yang sesungguhnya. Manusia ditempatkan pada kedudukan yang tinggi, yaitu pada kepentingan manusia atau nilai-nilai misinya dalam hidup ini melalui konsentrasi perkembangan pribadinya. ${ }^{30}$

\section{Ekstensialisme dalam Pendidikan}

\section{Pandangan Eksistensialisme Terhadap Beberapa Faktor Pendidikan}

Eksistensialisme sebagai filsafat sangat menekankan individulitas dan pemenuhan diri secara pribadi. Setiap individu dipandang sebagai makhluk unik, dan secara unik pula ia bertanggungjawab terhadap nasibnya. Eksistensialisme berhubungan sangat erat dengan pendidikan karena keduanya bersinggungan satu sama lain pada masalah-masalah yang sama, yaitu manusia, hidup, hubungan antar manusia, hakikat kepribadian, dan kebebasan (kemerdekaan). Pusat pembicaraan eksistensialisme adalah "keberadaan" manusia, sedangkan pendidikan hanya dilakukan oleh manusia.

Menurut Zuhairini, pandangan eksistensialisme terhadap pendidikan, disimpulkan oleh Van Cleve Morris dalam Existentialism and Education, bahwa "Eksistensialisme tidak menghendaki adanya aturan-aturan pendidikan dalam segala bentuk. Oleh karena itu eksistensialisme dalam hal ini menolak bentuk-bentuk pendidikan sebagaimana yang ada sekarang. Gagasan pendidikan eksistensialisme diajukan oleh Morris sebagai "existentialism's concept of freedom in education". Salah satu model pendidikan eksistensialisme yang ditawarkan oleh Ivan Illich adalah Deschooling Society. ${ }^{31}$ Meskipun

\footnotetext{
${ }^{29}$ Arif Rohman, Rukiyati, L. Andriani.Arif Rohman, Rukiyati, L. Andriani, loc.cit.

${ }^{30}$ Muzairi, op. cit., hlm. 50

${ }^{31}$ Zuhairini, op. cit., h. 31.Deschooling Society adalah tidak adanya keseragaman dalam pendidikan. Jadi pendidikan yang dikehendaki oleh eksistensialisme bebas dan bertanggung jawabuntuk menumbuhkembangkan anak sesuai dengan potensi yang ada dalam dirinya. Kalau keseragaman diberlakukan, maka akan sulit mengembangkan anak sesuai potensinya.
} 
model ini banyak mendapat reaksi di kalangan ahli pendidikan, namun masa sekarang tampak model pendidikan cukup menarik perhatian.

Pengaruh eksistensialisme dalam pendidikan terutama dalam memotivasi dan memfasilitasi pembelajaran dalam makna yang sangat luas. Menjaga mood dalam kelas, memerlukan keseimbangan antara guru dan anak didik dalam mempertahankan identitasnya sebagai persona. ${ }^{32}$ Berikut implikasi aliran filsafat eksistensialisme dalam dunia pendidikan.

\section{a. Tujuan Pendidikan}

Tujuan pendidikan adalah untuk mendorong setiap individu agar mampu mengembangkan semua potensinya untuk pemenuhan diri dan memberi bekal pengalaman yang luas dan komprehensif dalam semua bentuk kehidupan. Setiap individu memiliki kebutuhan dan perhatian yang spesifik berkaitan dengan pemenuhan dirinya, sehingga dalam menentukan kurikulum tidak ada kurikulum yang pasti dan ditentukan berlaku secara umum.

\section{b. Peran Pendidik}

Menurut eksistensialisme peranan pendidik sebagai sebagai pembimbing dan mengarahkan siswa dengan seksama sehingga siswa mampu berpikir relative. Pendidik hadir dalam kelas dengan wawasan yang luas agar betul-betul menghasilkan diskusi tentang mata pelajaran yang diajarkan. Secara spesifik peranan pendidik adalah sebagai berikut:

1. Menemukan pembawaan pada anak didiknya dengan jalan observasi, wawancara, pergaulan, angket dan sebagainya.

2. Berupaya menolong anak didik dalam perkembangannya. Agar pembawaan buruk tidak dapat berkembang dengan subur mendekati kemungkinannya.

3. Menyajikan dan mencarikan jalan yang terbaik dan menunjukkan perkembangan yang tepat.

4. Setiap waktu mengadakan evaluasi untuk mengetahui apakah perkembangan anak didik dalam usaha mencapai pendidikan seperti yang diharapkan.

5. Memberikan bimbingan dan penyuluhan pada anak didik pada waktu mereka menghadapi kesulitan dengan cara yang sesuai dengan kemampuan anak didik dan tujuan yang dicapai.

6. Dalam menjalankan tugasnya, pendidik wajib selalu ingat bahwa anak sendirilah yang berkembang berdasarkan bakat yang ada padanya.

7. Pendidik senantiasa mengadakan penilaian atas diri sendiri untuk mengetahui apakah hal-hal yang tertentu dalam diri pribadinya yang harus mendapatkan perbaikan.

8. Pendidik perlu memilih metode atau teknik penyajian yang tidak saja disesuaikan dengan bahan atau isi pendidikan yang akan disampaikan namun disesuaikan dengan kondisi anak didiknya. ${ }^{33}$

\footnotetext{
${ }^{32}$ Arif Rohman, Rukiyati, L. Andriani.Arif Rohman, Rukiyati, L. Andriani, op.cit. hlm. 117

${ }^{33}$ Charles Simbolon, Jejak Pendidikan:Filsafat Eksistensialisme. charlessimbolon. blogspot.co.id./ 2014. (5 November 2015)
} 
Para guru harus memberikan kebebasan kepada siswa memilih dan memberi mereka pengalaman-pengalaman yang akan membantu mereka menemukan makna dari kehidupan mereka.

Guru hendaknya memberi semangat kepada siswa untuk memikirkan dirinya dalam suatu dialog. Guru menanyakan tentang ide-ide yang dimiliki siswa, dan mengajukan ide-ide lain, kemudian guru membimbing siswa untuk mengarahkan siswa dengan seksama sehingga siswa mampu berpikir relatif dengan melalui pertanyaanpertanyaan.

\section{c. Peserta Didik}

Aliran eksistensialisme memandang siswa sebagai makhluk rasional dengan pilihan bebas dan tanggung jawab atas pilihannya dan siswa dipandang sebagai makhluk yang utuh yaitu yang akal pikiran, rohani, dan jasmani yang semua itu merupakan kebulatan dan semua itu perlu dikembangkan melalui pendidikan. Dengan melaksanakan kebebasan pribadi, para siswa akan belajar dasar-dasar tanggung jawab pribadi dan sosial.

\section{d. Kurikulum}

Kurikulum ideal adalah kurikulum yang memberi para siswa kebebasan individual yang luas dan mensyaratkan mereka untuk mengajukan pertanyaan-pertanyaan, melaksanakan pencarian-pencarian mereka sendiri, dan menarik kesimpulan mereka sendiri.Menurut pandangan eksistensialisme, tidak ada satu mata pelajaran tertentu yang lebih penting daripada yang lainnya. Mata pelajaran merupakan materi dimana individu akan dapat menemukan dirinya dan kesadaran akan dunianya.

Kurikulum eksistensialisme memberikan perhatian yang besar terhadap humaniora dan seni. Karena materi tersebut diperlukan agar individu dapat mengadakan introspeksi dan mengenalkan gambaran dirinya. Pelajaran harus didorong untuk melakukan kegiatan-kegiatan yang dapat mengembangkan keterampilan yang dibutuhkan, serta memperoleh pengetahuan yang diharapkan. Seni dirancang untuk menumbuhkan pengalaman estetis, termasuk bentuk-bentuk seperti music, drama, tari, menulis kreatif, lukisan, dan film. Tujuan pendidikan estetika, menurut eksistensialisme, bukan untuk meniru gaya artis model yang dipilih, melainkan untuk merangsang ekspresi estetika.

Menurut pandangan eksistensialisme, tidak ada satu mata pelajaran tertentu yang lebih penting daripada yang lainnya. Mata pelajaran merupakan materi dimana individu akan dapat menemui dirinya dan kesadaran akan dunianya. Mata pelajaran yang dapat memenuhi tuntutan diatas adalah mata pelajaran IPA, Sejarah, Sastra, Filsafat, dan Seni. Bagi beberapa anak, pelajaran yang dapat membantu untuk menemukan dirinya adalah IPA, namun bagi yang lainnya mungkin saja bisa Sejarah, Filsafat, Sastra, dan lain sebagainya. ${ }^{34}$

\section{e. Metode}

Dalam metodologi eksistensialisme, guru merangsang "intensitas kesadaran" si pelajar dengan mendorong pencarian kebenaran pribadi dengan mengajukan pertanyaan makna kehawatiran hidup. Ini adalah tugas guru untuk memberikan iklim 
dan situasi untuk ekspresisubjektivitas siswa. Diskusi merupakan metode utama dalam pandangan eksistensialisme. Siswa memiliki hak untuk menolak interpretasi guru tentang mata pelajaran. Sekolah merupakan suatu forum di mana para siswa mampu berdialog dengan teman-temannya, dan guru membantu menjelaskan kemajuan siswa dalam pemenuhan dirinya.

\section{f. Evaluasi}

Eksistensialisme berpandangan bahwa eksistensi di atas dunia selalu terkait pada keputusan-keputusan individu, artinya, andaikan individu tidak mengambil suatu keputusan maka pastilah tidak ada yang terjadi. Individu sangat menentukan terhadap sesuatu yang baik, terutama sekali bagi kepentingan dirinya. Jadi menurut aliran ini manusia itu sendirilah yang dapat menentukan seseuatu itu baik atau buruk. Ungkapan dari aliran ini adalah " Truth is subjectivity" atau kebenaran terletak pada pribadinya maka disebutlah baik, dan sebaliknya apabila keputusan itu tidak baik bagi pribadinya maka itulah yang buruk.

\section{g. Proses Belajar Mengajar}

Dalam proses belajar mengajar, pengetahuan tidak dilimpahkan, melainkan ditawarkan. Untuk menjadikan hubungan guru dengan murid sebagai suatu dialog, maka pengetahuan yang akan diberikan kepada murid, harus menjadi bagian dari pengalaman pribadinya, sehingga guru akan berjumpa dengan anak sebagai pribadi dengan pribadi. Pengetahuan yang ditawarkan guru, tidak lagi merupakan sesuatu yang diberikan kepada murid, melainkan merupakan suatu aspek yang telah menjadi miliknya sendiri.

Guru harus mampu membimbing dan mengarahkan siswa dengan seksama sehingga siswa mampu berpikir relatif melalui pertanyaan-pertanyaan. Dalam arti, guru tidak mengarahkan dan tidak memberi instruksi. Guru hadir dalam kelas dengan wawasan yang luas agar betul-betul menghasilkan diskusi tentang mata pelajaran. Diskusi ialah metode utama dalam pandangan eksistensialisme. Siswa memiliki hak untuk menolak interpretasi guru tentang pelajaran. Sekolah ialah suatu forum dimana para siswa mampu berdialog dengan teman-temannya, dan guru membantu menjelaskan kemajuan siswa dalam pemenuhan dirinya.

Guru hendaknya memberi semangat kepada murid untuk memikirkan dirinya didalam suatu dialog. Guru menanyakan tentang ide-ide yang dimiliki murid, dan mengajukan ide-ide lain, dan membimbingnya untuk memilih alternatif. Maka siswa akan melihat, bahwa kebenaran tidak terjadi kepada manusia melainkan dipilih oleh mereka sendiri. Lebih dari itu, siswa harus menjadi aktor dalam suatu drama belajar, bukan penonton. ${ }^{35}$

\section{Eksistensialisme sebagai Pendidikan Humanisme}

Sebagaimana kita uraikan di atas pada halaman 6 bahwa hanya manusia yang bereksistensi. Eksistensi adalah khas manusia berada. Pusat perhatian ini ada pada manusia. Oleh karena itu bersifat humanitis. Eksistensialisme mempunyai sifat dan corak humanisme. ${ }^{36}$

\footnotetext{
${ }^{35} \mathrm{Ibid}$

${ }^{36}$ Harun Hadiwijono, loc. cit. dan Muzairi, op. cit. hlm. 49
} 
Jean paul Sartre, umpamanya, menulis buku yang berjudul L'existensialisme est un bumanisme (Eksistensialisme dan humanisme) yang isinya adalah ceramah penegasan bahwa eksistensialisme menggunakan label “bumanisme”. Lalu rekan Sartre, Maurice M. ponty, menulis buku yang berjudul "Humanisme et terreur. Essai sur le problem communist (Paris, 1947). Kemudian buku ini diterjemahkan dalam bahasa Inggris dengan judul Hummanisme and Terror: An Essay on the Communist Probleme. Kemudian Jasper, pada tahun 1947 memberikan ceramah di Wina dengan judul "Kemungkinan-kemungkinan akan Humanisme Baru” yang mana ceramahnya diterjemahkan dalam bahasa Inggris dengan judul Existentialisme and Humanistoleh HE. Fischer, tahun 1952 di New York. ${ }^{37}$

Pemikiran eksistensialisme mempengaruhi perkembangan psikologi, ${ }^{38}$ yaitu psikologi humanistik yang membawa implikasi dalam psikologi pendidikan, teori belajar, dan psikologikonseling. ${ }^{39}$

\section{a.Psikologi pendidikan}

Para ahli psikologi pendidikan menyatakan bahwa pada dasarnya pendidikan humanistik bukanlah sebuah strategi belajar, melainkan sebagai filosofi belajar yang sangat memerhatikan keunikan-keunikan yang dimiliki siswa, bahwa setiap siswa mempunyai cara sendiri dalam dalam mengkonstruk pengetahuan yang dipelajarinya. Pembelajaran dengan pendekatan ini juga lebih menghargai domain-domain lain yang ada dalam diri siswa selain domain kognitif dan psikomotorik, sehingga dalam proses pembelajaran nilai-nilai kemanusiaan yang ada dalam diri siswa mendapatkan perhatian untuk dikembangkan. ${ }^{40}$ Salah satu teori humanistis dalam hal ini adalah Bloom dan Tathwool menunjukkan apa yang mungkin dikuasai oleh siswa yang tercakup dalam tiga hal, yaitu kognitif, afektif dan psikomotorik. ${ }^{41}$

Untuk itu, Miller (1976) menggagas sebuah model pendidikan yang menekankan pada humanizing classroom, memanusiakan ruang kelas. Maksudnya, dalam proses pembelajaran guru hendaknya memperlakukan siswa-siswanya sesuai dengan kondisi mereka masing-masing. Salah satu model pembelajaran itu adalah open schools atau "sekolah terbuka". ${ }^{42}$

Dalam open schools, proses pembelajaran memiliki ciri-ciri berikut. Pertama, Peran guru dan murid, di mana guru berperan sebagai fasilitator yang membantu siswa untuk aktif membimbing diri mereka sendiri dalam belajar, dan siswa juga secara aktif memilih materi, metode-metode, dan langkah-langkah dalam belajar; Kedua, Evaluasi diagnostik, evaluasi belajar siswa tidak hanya didasarkan pada tes, tapi juga

${ }^{37}$ Muzairi, ibid., hlm. 50.

${ }^{38}$ Banyak ahli psikologi yang berorentasi eksistensial yang mengajukan argumen menentang pembatasan studi tingkah laku manusia pada metode-metode yang digunakan ilmu pengetahuan alam. Sebagai contoh, Bugental (1965), Rogers (1961), Frankl (1959), Jourard (1968), Maslow(1968), Arbuckle (1975) yang mengemukakan kebutuhan psikologi akan suatu perspektif yang lebih luas yang mencakup pengalaman subjektif kliens atas dunia pribadinya.

${ }^{39}$ Arif Rohman, Rukiyati, L. Andriani.Arif Rohman, Rukiyati, L. Andriani, op.cit., hlm. 114.

${ }^{40}$ Baharuddin dan Esa Nur Wahyuni, Teori Belajar dan Pembelajaran (Yogyakarta: Ar-Ruzz Media Group, 2008), hlm. 143.

${ }^{41}$ Yatim Riyanto, Paradigma Baru Pembelajaran: Sebagai Referensi bagi Pendidik dalam Implementasi Pembelaajaran yang Efektif dan Berkualitas, Cet. 4 (Jakarta: Kencana, 2014), hlm 17.

${ }^{42}$ Baharuddin dan Esa Nur Wahyuni, op. cit., hlm. 144. 
pada pengamatan terhadap hasil karya dan performa siswa dalam belajar; Ketiga, pemberian materi yang berbeda-beda digunakan untuk memberikan stimulus bagi siswa agar dapat melakukan eksplorasi dalam belajar. Keempat, Pengajaran individual, dalam opens schools, sistem pengajaran didasarkan pada kebutuhan individual siswa. Kelima, Kelompok dengan berbagai tingkat usia; Keenam, Ruangan terbuka, ruangan dirancang sedemikian rupa sehingga ruangan dapat digunakan secara fleksibel untuk berbagai kegiatan belajar. Ketujuh, Team teaching, sistem pengajaran dapat direncanakan oleh dua atau lebih guru sebagai tim pengajar, sehingga guru dapat merencanakan pengajaran bersama, berbagi sumber belajar dan menggabungkan siswa. ${ }^{43}$

\section{b. Teori belajar}

Eksistensialisme dan humanisme juga tergambar dalam salah satu teori belajar yaitu teori Experiential Learning yang menekankan pada keinginan kuat dari siswa untuk berhasil dalam belajarnya.

Menurut experiential learning theory, agar proses belajar mengajar efektif, seorang siswa harus memiliki 4 kemampuan, seperti yang kita gambarkan dalam tabel berikut:

\section{Tabel 1}

Kemampuan siswa dalam proses belajar dalam eksperiential learning theory

\begin{tabular}{|l|l|l|}
\hline \multicolumn{1}{|c|}{ Kemampuan } & \multicolumn{1}{|c|}{ Uraian } & Pengutamaan \\
\hline Concrete Experience (CE) & $\begin{array}{l}\text { Siswa melibatkan diri } \\
\text { sepenuhnya dalam pengalaman } \\
\text { baru }\end{array}$ & Feeling (perasaan) \\
\hline $\begin{array}{l}\text { Reflection Observation } \\
\text { (RO) }\end{array}$ & $\begin{array}{l}\text { Siswa mengobservasi dan } \\
\text { merefleksi atau memikirkan } \\
\text { pengalamannya dari berbagai } \\
\text { segi }\end{array}$ & $\begin{array}{l}\text { Watching } \\
\text { (mengamati) }\end{array}$ \\
\hline $\begin{array}{l}\text { Abstract Conceptualization } \\
\text { (AC) }\end{array}$ & $\begin{array}{l}\text { Siswa menciptakan konsep- } \\
\text { konsep yang mengintegrasikan } \\
\text { observasinya menjadi teori } \\
\text { yang sehat }\end{array}$ & \\
\hline $\begin{array}{l}\text { Active Experimentation } \\
\text { (AE) }\end{array}$ & $\begin{array}{l}\text { Siswa menggunakan teori } \\
\text { untuk memecahkan masalah- } \\
\text { masalah dan mengambil } \\
\text { keputusan }\end{array}$ & Doing (berbuat) \\
\hline
\end{tabular}

Teori Experiential learning merupakan model pembelajaran yang sangat memerhatikan perbedaan atau keunikan yang dimiliki oleh siswa. Seorang siswa mungkin memiliki pengalaman yang berbeda dengan siswa lain. Masing-masing siswa juga mungkin memiliki gaya belajar yang unik dan berbeda dengan yang lainnya.

${ }^{43}$ Ibid., hlm. 145 
Keempat tahapan dalam experiential learning bertujuan untuk mengakomodasi perbedaan dan keunikan yang dimiliki oleh masing-masing individu. ${ }^{44}$

\section{c. Psikologi Konseling}

Konseling adalah proses yang melibatkan seseorang professional berusaha membantu orang lain dalam pemahaman dirinya (self-understanding), membuat keputusan dan pemecahan masalah. ${ }^{45}$

Ada beberapa pendekatan yang digunakan dalam konseling, salah satunya adalah pendekatan eksistensial-humanistik. Pendekatan eksistensial-humanistik menekankan renungan-renungan filosofis tentang apa aartinya menjadi manusia yang utuh. Terapi eksistensial terutama berpijak pada premis bahwa manusia tidak bisa melarikan diri dari kebebasan dan bahwa kebebasan dan tanggung jawab itu saling berkaitan. Pendekatan eksistensial-humanistik menyajikan suatu landasan filosofis bagi orang-orang dalam hubungan dengan sesamanya yang menjadi ciri khas, kebutuhan yang unik dan menjadi tujuan konselingnya, dan yang melalaui implikasi-implikasi bagi usaha membantu individu dalam menghadapi pertanyaan-pertanyaan dasar yang menyangkut keadaan manusia. ${ }^{46}$

Psikologi eksistensial-humanistik berfokus pada kondisi manusia. Pendekatan ini terutama adalah suatu sikap yang menekankan pada pemahaman atas manusia. Konsep-konsep utama dari pendekatan eksistensial yang membentuk landasan bagi praktik terapeutik adalah:

Kesadaran diri, manusia memiliki kesanggupan untuk menyadari dirinya sendiri, suatu kesanggupan yang unik dan nyata yang memungkinkan manusia mampu berpikir dan memutuskan. Semakin kuat kesadaran diri itu pada seseorang, maka akan semakin besar pula kebebasan yang ada pada orang itu. Kesanggupan untuk memilih, memutuskan adalah aspek yang esensial pada manusia. Para eksistensialis menekankan bahwa manusia bertanggung jawab atas keberadaan dan nasibnya. ${ }^{47}$

Kebebasan, tanggung jawab, dan kecemasan. Kesadaran atas kebebasan dan tanggung jawab bisa menimbulkan kecemasan yang menjadi atribut dasar pada manusia. Kecemasan eksistensial juga bisa diakibatkan oleh kesadaran atas keterbatasannya dan kemungkinan yang tak dapat dihindari yaitu kematian. Kesadaran akan kematian memiliki arti penting bagi kehidupan individu dan kenyataan bahwa manusia memiliki waktu yang terbatas untuk mengaktualkan potensi-potensinya.

Penciptaan makna. Manusia itu unik, dalam arti bahwa dia berusaha untuk menemukan tujuan hidup dan menciptakan nilai-nilai yang akan memberikan makna ${ }^{44}$ Ibid., hlm. 166-168.

${ }^{45}$ Latipun, Psikologi Konseling, Cet. 6 (Malang: UMM, 2006), hlm. 5. Kata konseling (counseling) berasal dari kata counsel yang diambil dari bahasa Latin yaitu Counselium, artinya "bersama" atau "bicara bersama". Pengertian "berbicara bersama-sama" dalam hal ini adalah pembicarakan konselor dengan seorang atau beberapa klien. Dengan demikian counselium berarti "people coming together to gain an understanding of problem that beset them were evident", demikian ditulis oleh Baruth dan Robinson menjelaskan secara singkat dalam bukunya An Introduction to The Counseling Profession, (Englewood Cliffs, New Jersey: Prentice-Hall,Inc, 1987), hlm. 2.

${ }^{46}$ Gerald Corey, Teori dan Praktik Konseling dan Psikoterapi, Terjemahan (Bandung: PT Refika Aditama, 2003), hlm. 53.

${ }^{47}$ Ibid., hlm. 54. 
bagi kehidupan. Menjadi manusia juga berarti menghadapi kesendirian: Manusia lahir ke dunia sendirian dan mati sendirian pula. Sungguhpun pada hakikatnya sendirian, manusia memiliki kebutuhan untuk berhubungan dengan sesamanya dalam suatu cara yang bermakna. Kegagalan dalam menciptakah hubungan yang bermakna bisa menimbulkan kondisi isolasi, depersonalisasi, alineasi, keterasingan dan kesepian. Manusia juga berusaha mengaktualisasikan dirinya yaitu dengan mengungkapkan potensi-potensi manusiawinya. Jika tidak mampu, ia bisa "sakit". Patologi dipandang sebagai kegagalan menggunakan kebebasan untuk mewujudkan potensi-potensi seseorang. ${ }^{48}$

Uraian di atas menunjukkan keunggulan dalam filsafat eksistensialisme. Adapun kelemahannya dapat dilihat dari implikasi eksistensialisme dalam kehidupan manusia, baik pada sikap subjektivitas dan individualitas manusia,sehingga orang cenderung bebas berbuat menurut jati dirinya dengan slogan be your self. Dalam bidang pendidikan, eksistensialisme kadang-kadang bisa merepotkan penyelenggara pendidikan. Hal ini bila pendidikan diarahkan kepada siswa atau peserta didik secara individual, maka sulit bagi pembuat kurikulum dalam menyusun kurikulum, bagi pembuat teori dalam membuat model pembelajaran, karena setiap individu tentu berbeda kemampuan, kecerdasan dan mereka memiliki karakteristik dan keunikan masing-masing.

Nah, untuk itu perlu adanya gagasan kreatif, ketekunan dan spirit yang kuat bagi penyelenggara pendidikan dan pembuat kurikulum termasuk guru bagaimana melaksanakan pendidikan, sehingga tujuan utama pendidikan yang diinginkan oleh ahli pendidikan eksistensialisme yaitu menumbuhkembangkan potensi siswa/peserta sesuai dengan potensi yang ada pada dirinya bisa diwujudkan.

\section{Eksistensialisme dan Islam: Sebuah Analisis}

Konsep Islam tentang eksistensialisme khususnya dalam pendidikan terlihat dari perhatian yang besar terhadap anak sebagai individu. Rasulullah saw. bersabda:

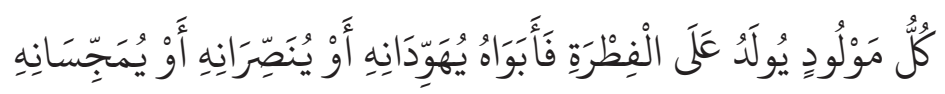

"Setiap anak dilabirkan dalam keadaan suci. Kedua orang tuanyalah yang akan membuatnya Yahudi, Nasrani, ataupun Majusi"

Kemudian diperkuat lagi dengan Al-Qur'an surah Ar-Rum ayat 30, yaitu:

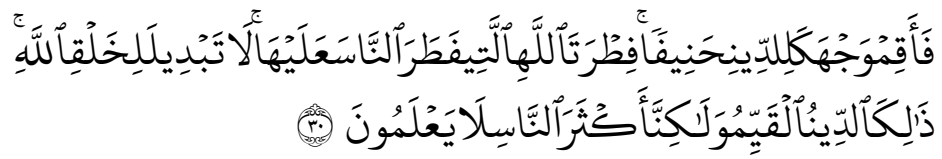

"Maka hadapkeanlah wajahmu dengan lurus kepada agama Allab; (tetaplah atas) fitrah Allah yang telah menciptakan manusia menurut fitrah itu. Tidak ada perubahan pada fitrah Allah. (Itulah) agama yang lurus; tetapi kebanyakan manusia tidak mengetabui."

${ }^{48}$ Ibid. hlm., 55. 
Menurut Al-Ghazali fitrah adalah suatu sifat dari dasar manusia yang dibekali sejak lahirnya dengan memiliki keistemewaan sebagai berikut:

1. Beriman kepada Allah swt.

2. Kemampuan dan kesediaan untuk menerima kebaikan dan keturunan atau dasar kemampuan untuk menerima pendidikan dan pengajaran.

3. Dorongan ingin tahu untuk mencari hakikat kebenaran yang merupakan daya untuk berpikir.

4. Dorongan biologis yang berupa syahwat dan ghadlob atau insting.

5. Kekuatan-kekuatan lain dan sifat-sifat manusia yang dapat dikembangkan dan disempurnakan. ${ }^{49}$

Al-Quran dan hadis serta pendapat Al-Ghazali di atas menunjukkan bahwa Islam memandang dan menempatkan individu manusia sejak lahirnya sudah mempunyai potensi untuk seterusnya dikembangkan sesuai dengan kemampuannya. Al-Ghazali juga mengemukakan bahwa perkembangan seorang anak itu dimulai dari kandungan yang disebut dengan al-janin, kemudian al-tifl, al-tamyiz, al-aqil dan selanjutnya al-Auliya sebagai tingkat tertinggi perkembangan manusia. ${ }^{50}$

Di sini Islam memberikan kedudukan yang sangat mulia kepada manusia.Di sini pula Al-Ghazali menguraikan bahwa manusia itu berkembang sejak dalam kandungan sampai lahir ke duniabahkan manusia itu sampai pada tingkat tertinggi dan terakhir yakni tingkat kewalian atau kenabian, di mana pada tingkat ini manusia sudah mampu mencapai tujuan pendidikan Islam yakni mendekatkan diri kepada Allah swt. dan menjadi pribadi yang sempurna. Ini menjadi pembeda bagi pemikiran barat dari timur.

Pendidikan merupakan upaya bimbingan, pemeliharaan, pembinaan, pengasuhan terhadap potensi yang dimiliki oleh anak, agar ia tumbuh dan berkembang secara optimal untuk mencapai tujuan pendidikan yang sesuai dengan konsep Al-Qur'an. Al-Qur'an dan Hadis merupakan esensi dari pendidikan Islam.

Kalau kita cermati bersama, pendidikan Islam itu mempunyai tujuan lebih dibandingkan dengan pendidikan non-Islam. Nilai lebih itu terlihat bahwa sistem pendidikan Islam dirancang agar dapat merangkum tujuan hidup manusia sebagai makhluk ciptaan Tuhan, yang pada hakikatnya tunduk pada hakikat penciptaannya. Hal ini dapat dirinci:Pertama, Tujuan pendidikan Islam bersifat fitrah, yaitu membimbing perkembangan manusia, sejalan dengan fitrah kejadiannya.Kedua, Tujuan pendidikan Islam, merentang dua dimensi, yaitu tujuan akhir bagi keselamatan hidup di dunia dan akhirat.Ketiga, Tujuan pendidikan Islam mengandung nilai-nilai yang bersifat universal yang tak terbatas oleh ruang lingkup geografis dan paham-paham tertentu. ${ }^{51}$

Ringkasnya tujuan akhir pendidikan Islam adalah berupaya mewujudkan pribadi muslim yang sempurna, yang bisa mengemban fungsinya sebagai 'abid dan khalifah di muka bumi. Tujuan pendidikan Islam terangkum dalam cita-cita setiap muslim dan muslimat, yaitu mendapat kebahagiaan di dunia dan kebahagiaan di akhirat.

\footnotetext{
${ }^{49}$ Zainuddin, Seluk-Beluk Pendidikan Islam dari Al-Ghazali (Jakarta: Bumi Aksara, 1991), hlm. 65.

${ }^{50}$ Ibid., hlm. 68.

${ }^{51}$ Jalaluddin dan Usman Said, op. cit., hlm. 39.
} 
Ibnu Khaldun ${ }^{52}$ menganjurkan agar bersikap kasih sayang kepada anak dan tidak menggunakan kekerasan kepada mereka, karena sikap kasar atau kekerasan dalam mendidik membahayakan jasmani anak. Jika anak diperlakukan secara kasar dan keras, menjadi sempit hatinya, dan hilang kecerdasannya, bahkan ia akan terdorong untuk berdusta, malas, dan berbuat kotor, dan saat itu anak tidak dapat menyatakan apa yang bergetar dalam hati kecilnya, akhirnya rusaklah makna kemanusiaan dalam dirinya sejak masa kanak-kanak. ${ }^{53}$

Jadi, pada dasarnya pendidikan Islam dengan landasan Al-Quran dan hadisnya telah memberikan pedoman yang sangat ideal bahwa manusia sebagai individu mempunyai potensi dasar yang baik dan harus dikembangkan sehingga bisa menjadi pribadi yang sempurna atau insankamil yang memperoleh kebahagiaan di dunia dan di akhirat

Adapun eksistensialisme ini, jika dikaji menurut pandangan para tokoh Islam, mungkin pandangan Muhammad Iqbal ${ }^{54}$ bisa dianggap tepat, karena beliau ada berbicara tentang ego ${ }^{55}$ (pribadi manusia) dalam bukunya Asrar-i-khudi.

Menurut Iqbal, yang dimaksud dengan ego atau khudi adalah sebuah ungkapan yang dapat menggambarkan "sebuah aku yang unik", kreatif dan senantiasa bergerak maju. Khudi adalah bermakna Self-Reliance (kepercayaan pada diri sendiri), Self-Resferct (rasa harga diri), Self Confidence (yakni percaya diri), Self Prevervation (penjagaan diri sendiri), bahkan Self Assertion (penegasan diri).

Menurut Iqbal, ego adalah pendorong daya kreatifitas pada setiap manusia. Setiap manusia memiliki ego yang berbeda. Karenanya, hasil kreasi yang mereka ciptakan juga tidak sama. Tuhan menurut Iqbal memberikan kebebasan penuh kepada setiap ego itu. Untuk berkreasi dan berekspresi. Iqbal sendiri menggambarkan Tuhan sebagai ego absolut yang paling berdaya kreatifitas sempurna.

Ego atau self atau individualitas merupakan sesuatu yang riil atau yang nyata, adalah pusat atau landasan dari semua kehidupan, merupakan suatu iradah kreatif yang terarah secara rasional. Arti terarah secara rasional, menjelaskan hidup bukanlah suatu

${ }^{52}$ Ibnu Khaldun hidup pada periode akhir dari dinasti Mamluk, yaitu periode sejarah keruntuhan peradaban Islam di Baghdad karena serangan bangsa Tartar tahun 656H/923M. Beliau mengabdikan dirinya kepada ilmu pengetahuan di Mesir sampai akhir hayatnya pada tahun $808 \mathrm{H}$.

${ }^{53}$ Ali Al-Jumbulati, Dirasatun Muqaranatun fi al-Tarbiyati al-Islamiyah. Diterjemahkan oleh M. Arifin, Perbandingan Pendidikan (Jakarta: Rineka Cipta, 1994), hlm. 209.

${ }^{54}$ Iqbal dilahirkan di Sialkot-India (suatu kota tua bersejarah di perbatasan Punjab Barat dan Kashmir) pada tanggal 9 November 1877/ 2 Dzulqa'dah 1294, dan wafat pada tanggal 21 April 1938. Meski terlahir dari keluarga miskin, berkat kecerdasannya dalam memahami ilmu, bantuan beasiswa ia peroleh dari tingkat sekolah menengah hingga perguruan tinggi. Iqbal pun mendapatkan pendidikan yang baik. Setelah pendidikan dasarnya selesai di Sialkot, ia masuk Government College (Sekolah Tinggi Pemerintah) Lahore. Ayah M. Iqbal bernama Nur Muhammad, seorang pedagang muslim yang taat beribadah dan sufi, Karena kesalehan dan kecerdasannya, penjahit yang cukup berhasil ini dikenal memiliki perasaan mistis yang dalam serta rasa keingintahuan ilmiah yang tinggi. Tak heran, jika Nur Muhammad dijuluki kawan-kawannya dengan sebutan "Sang Filosof tanpa guru.

${ }^{55}$ Iqbal menyebut ego dengan khudi. Perkataan khudi adalah berasal dari bahasa Persia, kata khud berarti diri, (self), sedang khudi berarti sifat mementingkan diri sendiri, arogansi, egoisme, Menurut pengertian ini jelaslah dilihat bahwa khudi tersebut adalah suatu kekuatan. 
arus tak terbentuk, melainkan suatu prinsip kesatuan yang bersifat mengatur, suatu kegiatan yang sintesis yang melingkupi serta memusatkan kecendrungan-kecendrungan yang bercerai-berai dari organisme yang hidup kearah satu tujuan konstruktif.

Khudi dalam bahasa Persia berarti pribadi. Yaitu pribadi-pribadi yang sempurna. Sedangkan yang dimaksud Iqbal di sini adalah usaha menjadikan diri Individu yang selalu diliputi sifat-sifat Tuhan yang sempurna. Ini terlihat ketika Iqbal melukiskan kejayaan pribadi dan jalan hidup Nabi Muhammad saw. Yang mana dalam tafsir sajaknya bahwa untuk perkembangan sewajarnya dari setiap muslim dirindukannya suatu masyarakat menurut acuan Islam, dan setiap muslim yang berusaha akan menjadikan dirinya individu yang sempurna turut membina kerajaan Islam dibumi ini.

Jadi menurut Iqbal bahwa pribadi sempurna adalah pribadi yang dapat mencontoh sifat- sifat Tuhan dalam egonya.Pribadi atau khudi itu ialah action hidup dan hidup ialah pribadi.Tuhan menjelmakan sifat-sifatnya bukanlah di alam ini dengan sempurna tetapi pada para pribadi sehingga mendekati Tuhan berarti menumbuhkan sifat-sifatNya dalam diri, yang sebenarnya sesuai dengan hadist Rasullah saw.: Takhallaqu bi akblaqillah, tumbuhkanlah dalam dirimu sifat-sifat Allah.Jadi mencari Tuhan bukanlah dengan jalan merendah-rendahkan diri atau meminta-minta, tetapi dengan himmah tenaga yang berkobar-kobar menjelmakan sifat-sifat uluhiyyah (ketuhanan) dalam diri kita dan kepada masyarakat ramai. Tegasnya mendekati Tuhan ialah menyempurnakan diri pribadi insan, memperkuat iradah atau kemauannya.Maka menurut Iqbal pribadi sejati adalah bukan yang menguasai alam benda tetapi pribadi yang dilingkupi Tuhan kedalam khudinya sendiri. ${ }^{56}$ Demikian menurut pendapat Iqbal.

Dalam bahasa Arab, kata existence berasal dari akar kata wajada yang berarti to find, serta kata turunannya: wujud (existence), wijdan (conscience), wajd (nirvana), serta wujd. Bilamana digunakan dalam bentuk, wajd, wujd, dan wijdan, maka dapat berarti to have property yang berkonsekuensi independence. Dalam QS. Al-Thalaq ayat 6, kata minwijdikum diartikan sebagai "menurut kemampuanmu". Sedang dalam QS. Al-Taubah ayat 5, kata haitsuwajadtumuhum diartikan sebagai "kamu jumpai mereka. Dapat dikatakan bahwa eksistensialisme atau falsafahwujudiyah, dalam Islam, bicara soal ada, kesadaran, kepemilikan, kemampuan, dan lain-lain yang terkait dalam kehidupan manusia. ${ }^{57}$

Inti eksistensialisme dalam pandangan Barat adalah pentingnya makna individualitas. Pandangan ini memiliki kesamaan dengan pendapat para filosof muslim. Kedua pandangan tersebut sama-sama menekankan bahwa kemanusiaan secara keseluruhan perlu mempertimbangkan alasan bagi eksistensinya. Hanya saja para eksistensialis muslim memberikan makna dan nilai dalam kehidupan manusia tidak hanya untuk kehidupan dunia tapi juga kehidupan akhirat. Ini yang membedakan dengan pandangan filosof Barat.

Jalaluddin Rumi memandang bahwa eksistensi ada dalam dua kategori, yaitu eksistensi Allah swt. yang kekal (eternal) dan eksistensi makhluk yang sementara (temporary). Al-Rumi menyatakan bahwa krisis itu terjadi karena kenyataannya bahwa

${ }^{56}$ Hadi Fauzan, Filsafat Iqbal tentang Tuhan dan diri. Hadifauzan.blogspot.co.id/2013/04/Muhammad-iqbal-filsafat-tentang-tuhan.html. (7 November 2015).

${ }^{57}$ Abd. Rachman Assegaf, Filsafat Pendidikan Islam ( Jakarta: PT. RagaGrafindo Persada, 2011), hlm. 238. 
kita mengambil eksistensi temporary dan eternal sebagai dua hal yang berbeda dan kita tidak menyerahkan diri pada Zat Yang Maha Eternal tadi hanya dengan cara meminimalkan eksistensi diri kita sendiri, dan bahwa hanya dengan cara inilah kita bisa menghindari diri dari berhenti dari hidup. Maka, menurutnya, tujuan pendidikan adalah menyatukan diri dengan Zat Yang Maha Eternal melalui penolakan terhadap eksistensi diri sendiri. ${ }^{58}$

Mulla Shadra memandang eksistensi (wujud) sebagai Realitas. Dengan persiapan mental dan penyucian jiwa tanpa selubung-selubung nafsu, seseorang dapat melihat wujud sebagai Realitas. Konsekuensi dari pengalaman tentang wujud adalah realisasi (kesadaran) akan kesatuannya, yang disebut sebagai wahdah al-wujud. Doktrin lainnya adalah tasykik al-wujud, di mana wujud bergradasi, dari wujud Tuhan hingga eksistensi sebutir pasir di pantai. Pandangan tentang wujud dilengkapi lagi dengan ashalah alwnjud atau keutamaan eksistensi. ${ }^{59}$

Berbeda dengan Barat, ada penganut atheism-existentialism menolak Tuhan seraya menempatkan manusia dalam posisi ada menurut ide mereka. Dalam ide mereka bahwa manusia tidak diciptakan oleh sesuatu yang lain dan bahwa manusia menciptakan dirinya sendiri. Jadi, eksistensi manusia ada lebih dahulu daripada esensinya.

Dalam sudut pandang Islam, makna existence precedes essence dinisbahkan kepada Allah swt. semata. Menurut para filosof Muslim penisbatan kepada Allah swt. ini tidak akan menjerumuskan falasafahwujudiyah atau eksistensialisme versi Islam ke dalam jebakan atheism.

Al-Qur'an menggambarkan eksistensi manusia sebagai makhluk pilihan Allah swt., sebagai khalifah-Nya di muka bumi yang dalam dirinya ditanamkan sifat mengakui Allah swt., bebas, bertanggung jawab terhadap dirinya maupun alam semesta serta mendapat karunia keunggulan atas alam semesta, langit dan bumi. Manusia diberikan kecenderungan kebaikan dan keburukan, kelemahan dan ketidakmampuan bergerak menjadi ke arah kekuatan. Manusia bebas dan diberi kemampuan belajar dan menerapkan ilmu, memiliki keluhuran dan martabat naluriah. Manusia dapat memanfaatkan rahmat dan karunia yang dilimpahkan kepada dirinya, namun pada saat yang sama, ia harus tunduk dan menunaikan kewajiban kepada Tuhan.

Bila manusia menjalankan kewajibannya kepada Allah swt., ia akan tetap dalam statusnya sebagai makhluk yang mulia, fitrah dan sebagai khalifah. Manusia memiliki martabat kemuliaan disebabkan: Pertama, bahwa manusia tidak berasal dari hewan; Kedua, manusia memiliki bentuk fisik yang lebih baik, QS. Al-Tin: 4; Ketiga, manusia mempunyai jasmani dan rohani, di mana di dalamnya terdapat rasio, emosi, dan konasi. Keempat, untuk mencapai kemuliaan martabat manusia harus berusaha melawan hawa nafsunya sendiri yang mendorong kejahatan; Kelima, manusia diangkat oleh Allah swt. sebagai khalifah di muka bumi dengan tugas menjadi penguasa yang mengelola dan memakmrkan bumi beserta isinya dengan sebaiknya QS. Al-Baqaeah: 30, dan QS. Huud: 61; Keenam, diciptakan segala sesuatu oleh Allah swt, untuk kepentingan manausia; Ketujuh, manusia diberi beban untuk beragama.

\footnotetext{
${ }^{58}$ Ibid., hlm. 240.

${ }^{59}$ Seyyed Hossien Nasr dan Olver Leaman, Ensiklopedi Tematis Filsafat Islam, (Buku kedua) Terjemahan (Bandung: Mizan, 2003), hlm. 915.
} 
Martabat manusia tidak diukur dari seberapa tinggi pangkat dan jabatannya, tapi diukur dari ketakwaannya. Makin bertakwa maka makin mulia. Sabda Rasulullah saw. bahwa sesungguhnya Allah swt. tidak melihat pada bentuk tubuh dan penampilan jasmani, melainkan sesungguhnya Allah swt. melihat hati dan perbuatan manusia. Jika perbuatan manusia tersebut baik, maka semakin mulialah kedudukan manusia di sisi Allah swt.

\section{Simpulan}

Sebagai penutup dari makalah ini akan kita simpulkan beberapa hal yang telah diuraikan di atas, yakni latar belakang munculnya eksistensialisme disebabkan adanya krisis pemikiran tentang manusia, baik itu materialisme, idealisme maupun krisis situasi manusia yang tidak menentu akibat perang dunia, di mana manusia seperti tidak mempunyai arti, maka eksistensialisme hadir untuk mendudukkan kembali keberadaan manusia.

Eksistensialisme adalah filsafat yang memandang segala gejala dengan berpangkal kepada eksistensi. Secara umum eksistensi berarti keberadaan. Secara khusus eksistensi adalah cara manusia berada di dalam di dunia. Cara manusia berada di dalam dunia berbeda dengan cara berada benda-benda. Benda-benda tidak sadar akan keberadaannya. Berbeda dengan manusia. Benda-benda menjadi lebih berarti karena manusia. Untuk membedakan dua cara berada ini di dalam filsafat eksistensialisme dikatakan, bahwa benda-benda "berada", sedangkan manusia "bereksistensi". Jadi hanya manusia yang bereksistensi. Tokoh-tokohnya adalah Soren Aabye Kierkegaard, Karl Jaspers, Martin Heidegger, Jean Paul Sartre, Friedrich Nietzshe.

Secara ontologi, eksistensialisme memandang manusia secara individual adalah unik. Epistemologi eksistensialisme beranggapan bahwa individu itu bertanggung jawab terhadap pengetahuannya sendiri. Pengetahuan itu berasal dari dalam diri, yaitu kesadaran individu dan perasaan-perasaannya sebagai hasil pengalaman masing-masing individu. Aksiologinya manusia ditempatkan pada kedudukan yang tinggi, yaitu pada kepentingan manusia atau nilai-nilai misinya dalam hidup ini melalui konsentrasi perkembangan pribadinya.

Pengaruh eksistensialisme dalam pendidikan terutama dalam memotivasi dan memfasilitasi pembelajaran dalam makna yang sangat luas. Implikasi aliran filsafat eksistensialisme dalam dunia pendidikan bisa dilihat dari tujuan pendidikan, peran pendidik, peserta didik, kurikulum, metode, evaluasi dan proses belajar mengajar di mana pendidik dan peserta didik menyadari siapa dirinya. Pemikiran eksistensialisme mempengaruhi perkembangan psikologi, yaitu psikologi humanistik yang membawa implikasi dalam psikologi pendidikan, teori belajar, dan psikologi konseling.

Islam sangat memuliakan manusia, bahkan tujuanakhir dalam pendidikan Islam adalah berupaya mewujudkan pribadi muslim yang sempurna, yang bisa mengemban fungsinya sebagai 'abid dan khalifah di muka bumi. Bahkan pandangan tokoh Islam tentang eksistensialisme menempatkan manusia sangat tinggi yakni insan kamil, sehingga jika dikaitkan dengan pendidikan, maka tujuan pendidikannya terangkum dalam cita-cita setiap muslim dan muslimat, yaitu mendapat kebahagiaan di dunia dan kebahagiaan di akhirat. 


\section{Daftar Pustaka}

Abidin, Zainal. 2003. Filsafat Manusia. Bandung: Rosdakarya.

Al-Jumbulati, Ali. 1994. Dirasatun Muqaranatun fi al-Tarbiyati al-Islamiyah. Diterjemahkan oleh M. Arifin, Perbandingan Pendidikan. Jakarta: Rineka Cipta.

Assegaf, Abd. Rachman. 2011. Filsafat Pendidikan Islam. Jakarta: PT. RagaGrafindo Persada.

Baharuddin dan Esa Nur Wahyuni. 2008. Teori Belajar dan Pembelajaran. Yogyakarta: Ar-Ruzz Media Group.

Baruth dan Robinson. 1987. An Introduction to The Counseling Profession. Englewood Cliffs, New Jersey: Prentice-Hall,Inc.

Corey, Gerald. 2003. Teori dan Praktik Konseling dan Psikoterapi, Terjemahan. Bandung: PT Refika Aditama.

Fauzan, Hadi. Filsafat Iqbal tentang Tuhan dan diri. Hadifauzan.blogspot.co.id/2013/04 /Muhammad-iqbal-filsafat-tentang-tuhan.html. (7 November 2015).

Hadiwijono, Harun. 1980. Sari Sejarah Filsafat Barat 2. Yogyakarta: Kanisius.

Hakim, Atang Abdul dan Beni Ahmad Saebeni. 2008. Filsafat Umum : Dari Mitologi Sampai Teofilosofi. Bandung: Pustaka Setia.

Jalaluddin dan Usman Said. 1994. Filsafat Pendidikan Islam. Jakarta: PT RajaGrafindo Persada.

Latipun. 2006. Psikologi Konseling, Cet. 6. Malang: UMM.

Marcuse, Herbert. 2004. Rasio dan Revolusi, Terjemahan. Yogyakarta: Pustaka Pelajar.

Muzairi. 2002. Eksistensialisme Jean Paul Sartre. Yogyakarta: Pustaka Pelajar.

Nasr, Seyyed Hossien dan Olver Leaman. 2003. Ensiklopedi Tematis Filsafat Islam, Buku kedua. Terjemahan. Bandung: Mizan.

Poedjawijatna, I.R. 1994. Pembimbing ke Arah Alam Filsafat. Jakarta: Rineka Cipta.

Riyanto, Yatim. 2014. Paradigma Baru Pembelajaran: Sebagai Referensi bagi Pendidik dalam Implementasi Pembelajaran yang Efektif dan Berkualitas. Cet. 4. Jakarta: Kencana.

Rohman, Arif., Rukiyati, L. Andriani. 2014. Epistemologi dan Logika: Filsafat untuk Pengembangan Pendidikan. Yogyakarta: Aswaja Pressindo.

Simbolon, Charles. Jejak Pendidikan: Filsafat Eksistensialisme.charlessimbolon.blogspot. co.id./2014. (5 November 2015)

Solihin, M. 2007. Perkembangan Pemikiran Filsafat dari Klasik Hingga Modern. Bandung: Pustaka Setia.

Tafsir, Ahmad. 2003. Filsafat Umum, Akal dan Hati Sejak Thales Sampai Capra. Bandung: PT Remaja Rosdakarya.

Zaprulkhan. 2012. Filsafat Umum: Sebuah Pendekatan Tematik. Jakarta: PT. RajaGrafindo Persada

Zainuddin. 1991. Seluk-Beluk Pendidikan Islam dari Al-Ghazali.Jakarta: Bumi Aksara. Zuhairini. 1992. Filsafat Pendidikan Islam. Jakarta: Bumi Aksara. 